\title{
PENGEMBANGAN MODEL PEMBELAJARAN KOOPERATIF JIGSAW YANG BERORIENTASI PADA KETERAMPILAN KOMUNIKASI ILMIAH MAHASISWA DALAM MATAKULIAH FISIKA KUANTUM
}

\author{
Mislan Sasono \\ Pendidikan Fisika FPMIPA IKIP PGRI Madiun, Email: mislan_fis03@yahoo.com
}

\begin{abstract}
ABSTRAK
Penelitian ini bertujuan: 1) mengembangkan perangkat pembelajaran fisika kuantum pokok bahasan persamaan Max Planck, Schrodinger, dan ketidakpastian Hiesenberg dengan model pembelajaran kooperati jigsaw yang berorientasi pada keterampilan komunikasi ilmiah mahasiswa, 2) memperoleh gambaran kualitas produk dan kualitas proses belajar mahasiswa dengan mengimplementasikan perangkat pembelajaran dalam pembelajaran kooperatif jigsaw, 3) mengetahui pengaruh pembelajaran kooperatif jigsaw terhadap keterampilan komunikasi ilmiah mahasiswa. Perangkat pembelajaran tersebut diimplikasikan oleh dosen model pada matakuliah fisika kuantum dan dengan terpenuhinya tujuan tersebut diharapkan keterampilan komunikasi ilmiah mahasiswa dan hasil belajar meningkat melalui model pembelajaran kooperatif jigsaw.

Penelitian ini termasuk ke dalam penelitian pengembangan (Developmental Research). Dalam mengembangkan perangkat pembelajaran digunakan Four-D Model, yaitu tahap pendefinisian (define), tahap perancangan (design), tahap pengembangan (develop), tahap ujicoba terbatas (disseminate). Perangkat pembelajaran yang telah berhasil dikembangkan didiseminasikan satu kali untuk tiga kali pembelajaran pada mahasiswa fisika kelas VIB IKIP PGRI Madiun. Setiap perangkat pembelajaran yang dikembangkan divalidasi oleh pakar, di samping itu untuk data pengamatan dilakukan iterasi (perulangan). Setiap komunikasi dan hasil belajar siswa selama pembelajaran dicatat sebagai data kuantitatif dan dianalisis secara deskriptif kualitatif.

Berdasarkan hasil penelitian dapat disimpulkan bahwa: Langkah-langkah pengembangan perangkat pembelajaran model kooperati jigsaw yang berorientasi keterampilan komunikasi ilmiah mahasiswa pada matakuliah fisika kuantum, mengikuti pola 4-D Model : Define, Design, Develop, Disseminate. Tahap Define ditandai dengan dihasilkannya kebutuhan-kebutuhan di dalam proses pembelajaran, Design ditandai dengan hasil akhir berupa Draft awal perangkat pembelajaran yang akan dikembangkan, sedangkan tahap Develop berupa pengembangan perangkat pembelajaran lebih lanjut, dan sebagai akhir tahapan yaitu Disseminate dengan pengujian perangkat pembelajaran. Analisis deskriptif data aktivitas mahasiswa menunjukan bahwa perangkat pembelajaran yang dikembangkan mampu meningkatkan kecenderungan mahasiswa untuk melakukan komunikasi berkaitan dengan materi adalah 75,1\%, Analisis keterampilan komunikasi ilmiah mahasiswa menunjukan bahwa keterampilan komunikasi ilmiah mahasiswa sedang pada pembelajaran kooperatif jigsaw adalah 2,67 dan hasil belajar mahasiswa tuntas.
\end{abstract}

Kata Kunci: Model Pembelajaran, Kooperatif Jigsaw, Keterampilan Komunikasi Ilmiah 


\section{PENDAHULUAN}

Pendidikan

memegang

peranan yang sangat penting dalam proses peningkatan kualitas sumber daya manusia. Peningkatan kualitas pendidikan merupakan suatu proses yang terintegrasi dengan proses peningkatan kualitas sumber daya manusia, karena penyelenggaraan pendidikan baik di lingkungan sekolah maupun luar sekolah dapat melahirkan sumber daya manusia yang berkualitas jika pendidikan di sekolah difokuskan pada proses pembelajaran. (www.uny.ac.id: 11 November 2006). Melihat kenyataan yang terjadi pembelajaran belum memperlihatkan hasil yang optimal dikalangan mahasiswa, hal ini dapat dilihat dari masih rendahnya prestasi belajar mahasiswa baik di perguruan tinggi khususnya dalam pendidikan fisika. Hasil Study International Education Achivement menunjukkan bahwa kemampuan fisika mahasiswa di Indonesia pada urutan ke-40 dari 42 negara peserta (www.sampoernafoundation.org :11 November 2006).

Fisika kuantum sebagai bagian dari sains merupakan bahan dasar segala ilmu sains. Perkembangan dan kemajuan fisika sangat menentukan perkembangan teknologi yang dipakai manusia dalam rangka meningkatkan kesejahteraan hidupnya. Menyadari akan pentingnya peningkatan proses pembelajaran fisika, pemerintah telah berupaya mewujudkan hal tersebut melalui berbagai usaha pembangunan pendidikan yang lebih berkualitas, antara lain melalui pengembangan dan perbaikan kurikulum, sistem evaluasi, perbaikan sarana pendidikan, pengembangan dan pengadaan materi ajar, serta pelatihan bagi dosen dan guru (http://ssep.net/director.html: 13
November 2006). Upaya pemerintah tersebut belum menunjukkan hasil yang sesuai dalam meningkatkan proses pembelajaran fisika karena pada dasarnya proses pembelajaran fisika sangat ditentukan oleh dosen dan guru, materi, pola interaksi, media dan teknologi, situasi belajar dan model atau strategi yang digunakan dalam proses pembelajaran. Tersedianya perangkat pembelajaran juga merupakan salah satu faktor yang dapat menunjang proses pembelajaran berjalan dengan baik dan dapat meningkatkan mutu pendidikan. Perangkat pembelajaran memberikan kemudahan dan dapat membantu dosen dan guru dalam mempersiapkan dan melaksanakan kegiatan belajar mengajar di kampus dan kelas. Perangkat ini menyediakan sejumlah strategi untuk mendorong mahasiswa menggunakan gaya-gaya belajar berbeda. Dengan perencanaan yang seksama, kebutuhan untuk seluruh mahasiswa dapat dipenuhi dalam kelas.

Berdasarkan hasil pengamatan, bahwa dalam kegiatan pembelajaran fisika kuantum selama ini sebenarnya dosen bidang studi fisika sudah menerapkan pembelajaran berkelompok untuk menyampaikan konsep-konsep fisika. Beberapa tugas yang harus dikerjakan mahasiswa secara kelompok seperti mengerjakan praktikum di laboratorium, tugas mengerjakan soal-soal latihan, tugas membaca, dan masih banyak lagi tugas lainnya. Tetapi kalau dicermati, kegiatan kelompok tersebut bukan pembelajaran kooperatif. Tujuan dari kerja kelompok hanya menyelesaikan tugas. Kegiatan pembelajaran tersebut biasanya hanya didominasi oleh mahasiswa yang pandai, sementara mahasiswa yang memiliki kemampuan rendah kurang berperan dalam mengerjakan 
tugas kelompok. Di samping itu, mahasiswa tidak dibiasakan untuk bekerja sama, berkomunikasi, dan menghargai pendapat orang lain. Akibat cara kerja kelompok seperti ini menyebabkan mahasiswa dengan kemampuan kurang memperoleh hasil belajar fisika yang rendah, terjadi kesenjangan yang terlalu jauh antara hasil belajar mahasiswa yang pandai dengan hasil belajar mahasiswa yang kurang pandai.

Komunikasi ilmiah mahasiswa dapat dilakukan melalui lisan, tulisan atau kegiatan praktikum. Komunikasi yang diharapkan di kelas bukan komunikasi yang hanya menonjolkan mahasiswa tertentu tetapi komunikasi yang menyeluruh. Setiap mahasiswa yang terlibat dalam pembelajaran memiliki kesempatan yang sama untuk aktif dalam proses komunikasi pembelajaran. Misalnya, melalui diskusi, presentasikan hasil kerja, kesempatan bertanya, menanggapi permasalahan, dan mengemukakan pendapatnya. Kesempatan yang sama juga tetap diberikan meskipun mahasiswa dibagi dalam kelompok. Dosen sebagai fasilitator mempunyai kewajiban untuk membiasakan mahasiswa menyampaikan materi yang dipelajari, tanpa harus menonjolkan kemampuan masing-masing mahasiswa dalam melakukan presentasi.guru juga dianjurkan untuk menanamkan kerjasama antar mahasiswa dalam kelompok. Untuk mewujudkan hal tersebut, sangat diperlukan kreativitas dosen dalam mengelola pembelajaran di kelas dengan mendorong mahasiswa menjadi pembelajar fisika yang aktif, kreatif, dan kritis.

Dewasa ini telah banyak digunakan model pembelajaran kooperatif. Pembelajaran kooperatif merupakan suatu model pembelajaran yang banyak

dikembangkan. Beberapa ahli menyatakan bahwa model pembelajaran kooperatif tidak hanya unggul dalam membantu mahasiswa untuk memahami konsep-konsep, juga membantu mahasiswa menumbuhkan kemampuan kerja sama, berpikir kritis, dan mengembangkan sikap sosial mahasiswa. Keterampilan kooperatif menjadi semakin penting untuk menentukan keberhasilan menghadapi tuntutan lapangan kerja yang berorientasi pada kerja sama tim. Penerapan strategi pembelajaran kooperatif dalam pendidikan menjadi lebih penting. Penguasaan teknologi pembelajaran dan kemandirian aktif mahasiswa dalam belajar, dapat diwujudkan melalui masyarakat sekolah atau kelas dengan cara mengimplementasikan model pembelajaran tertentu, Model pembelajaran yang dipilih harus benar-benar sesuai dengan tujuan yang akan dicapai sesuai karakter materinya. Menurut Insih Wilujeng (2006: 3) Model pembelajaran kooperatif merupakan model pembelajaran yang banyak melibatkan interaksi mahasiswa secara aktif, karena proses pembelajaran kooperatif didasarkan pada kerja tim, masing-masing individu memiliki tanggung jawab yang sama dalam mencapai tujuan kelompok. Suharyanto (2005 :18) menyatakan bahwa tujuan pembelajaran kooperatif tidak hanya mempelajari materi, tetapi mahasiswa harus dapat mengembangkan keterampilanketerampilan kooperatifnya. Pembelajaran kooperatif, menekankan bahwa mahasiswa harus dapat menjelaskan materi yang telah dipelajarinya kepada mahasiswa lain baik sebelum diskusi maupun setelah diskusi. Cara ini memungkinkan 
mahasiswa untuk menguasai materi yang dapat diekspresikan melalui komunikasi kepada teman sebayanya. Materi fisika yang dipelajari perlu dikaitkan dengan kehidupan sehari-hari karena ilmu fisika mempunyai karakteristik yang berkaitan dengan mengamati, memahami, dan memanfaatkan gejala-gejala alam. Pembelajaran kooperatif diperkirakan sangat sesuai untuk meningkatkan keterampilan komunikasi ilmiah mahasiswa.

Terdapat bermacam-macam tipe pembelajaran kooperatif, salah satu model pembelajaran kooperatif yang dapat mengarahkan komunikasi ilmiah mahasiswa adalah model jigsaw. Lie A (1994 dalam www.damandiri.or.id: 13 November 2006) menyatakan bahwa jigsaw merupakan salah satu tipe model pembelajaran kooperatif yang fleksibel. Model ini menekankan pada kerjasama antara anggota kelompok untuk saling menjelaskan materi yang telah dipelajari. Ciri lain model jigsaw yang membedakan dengan model pembelajaran kooperatif lain adanya pembagian materi menjadi beberapa bagian. Setiap anggota kelompok menjadi ahli pada salah satu bagian materi, kemudian bertanggung jawab untuk mengajar anggota lain dalam satu kelompok melalui kegiatan diskusi, sebelumnya kelompok ahli harus melakukan pertemuan untuk berdiskusi mengenai bagian materi yang ditugaskan serta menyiapkan ringkasan presentasi untuk diajarkan kepada kelompok kecil masingmasing. Selain bertanggungjawab terhadap skor masing-masing, setiap mahasiswa juga bertanggung jawab terhadap skor tim.

Matakuliah fisika kuantum merupakan salah satu matakuliah dalam pembelajaran fisika yang diberikan pada program studi fisika dalam semester genap, pokok bahasan kalor dan perpindahanya terdiri dari beberapa sub pokok bahasan diantaranya persamaan Max Planck, Schrodinger, dan Ketidakpastian Hiesenberg. Pembelajaran fisika kuantum pokok bahasan tersebut lebih banyak berhubungan dengan kegiatan yang dialami mahasiswa dalam kehidupan sehari-hari, oleh karena itu guru harus dapat mengembangkan suatu model pembelajaran fisika yang mampu menjelaskan materi tersebut kepada mahasiswa.

Pelaksanaan pembelajaran fisika kuantum di IKIP PGRI Madiun sebagaimana disesuaikan dengan kurikulum fisika yang berlaku, baik tujuan maupun struktur materinya. Pengajaran fisika kuantum di IKIP PGRI Madiun masih terbatas pada produk atau fakta, konsep dan teori saja. Padahal fisika terdiri atar tiga komponen yaitu produk, proses, dan sikap. Melihat kenyataan tersebut, maka sangat diperlukan adanya pengembangan suatu model pembelajaran fisika yang dapat meningkatkan komunikasi aktif mahasiswa. Salah satu model tersebut adalah model pembelajaran kooperatif jigsaw.

Berdasarkan uraian di atas, perlu untuk melakukan penelitian dengan mengembangkan perangkat pembelajaran yang bercirikan model pembelajaran kooperatif jigsaw sebagai salah satu alternatif dalam mengatasi permasalahan pembelajaran fisika kuantum di IKIP PGRI Madiun. Penelitian ini berjudul "Pengembangan Model Pembelajaran Kooperatif Jigsaw yang Berorientasi pada Keterampilan Komunikasi Ilmiah Mahasiswa dalam Matakuliah Fisika Kuantum”. 


\section{METODE}

Penelitian ini merupakan penelitian pengembangan. Disebut penelitian pengembangan karena mengembangkan perangkat pembelajaran fisika kuantum kelas VI B yang bercirikan model pembelajaran kooperatif jigsaw. Perangkat pembelajaran yang dikembangkan meliputi Satuan Acara Perkuliahan, Lembar Kegiatan
Mahasiswa, dan Tes Hasil belajar. Berdasarkan tujuan tersebut, maka Pengembangan model pembelajaran dapat dilakukan melalui Pengembangan model 4-D (Four D Models). pengembangan tersebut dapat digambarkan melalui bagan pengembangan pada Gambar 2 . berikut:

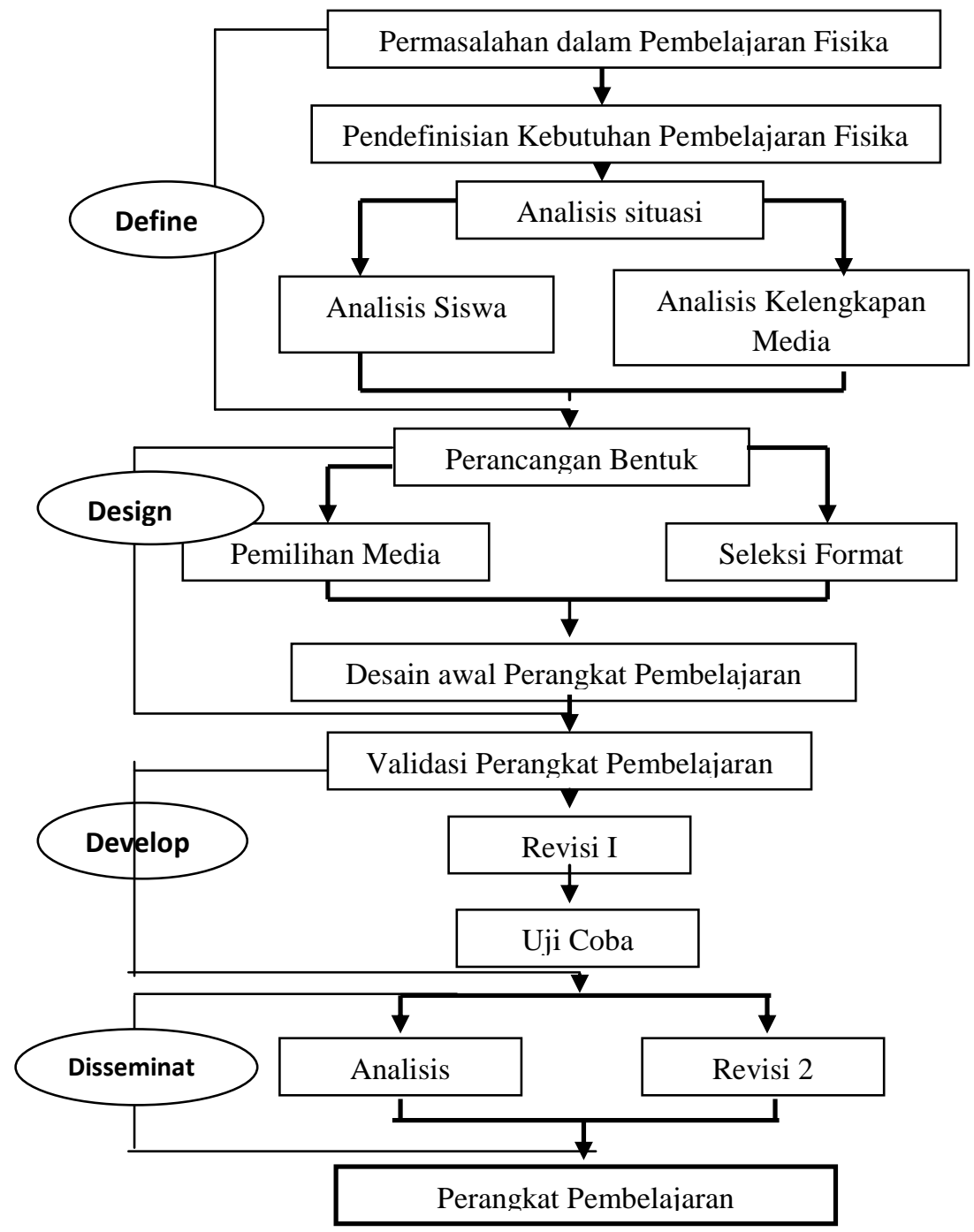

Gambar 2. Diagram Alir Pengembangan Perangkat Pembelajaran

Hasil pengembangan tersebut berupa perangkat pembelajaran yang

berorientasi pada pembelajaran kooperatif jigsaw.

\section{HASIL DAN PEMBAHASAN}

Pada dasarnya, penelitian ini dilakukan dalam 4 tahap, yaitu pendefinisian (Define), tahap perancangan (Design), tahap pengembangan (Develop), dan tahap Disseminasi (Disseminate). Tujuan dari penelitian ini adalah untuk memperoleh gambaran kualitas hasil 
dan kualitas proses belajar mahasiswa dengan mengembangkan dan mengimplementasikan perangkat pembelajaran pada pembelajaran kooperatif tipe jigsaw matakuliah fisika kuantum.

Kualitas

proses

pembelajaran dalam penelitian ini,

Tabel 11. Nilai Keterampilan Komunikasi Ilmiah Mahasiswa dalam Pembelajaran Kooperatif Jigsaw.

\begin{tabular}{|c|c|c|c|c|c|c|}
\hline \multirow[t]{2}{*}{$\mathrm{NO}$} & \multirow[t]{2}{*}{ Kategori pengamatan } & \multicolumn{4}{|c|}{ SAP ke- } & \multirow{2}{*}{$\begin{array}{l}\text { Nilai } \\
\text { Kategori }\end{array}$} \\
\hline & & I & II & III & $\begin{array}{l}\text { Rata- } \\
\text { rata }\end{array}$ & \\
\hline 1 & $\begin{array}{l}\text { Relevansi informasi dengan } \\
\text { permasalahan yang dibahas } \\
\text { Keluasan dalam }\end{array}$ & 2,6 & 2,8 & 2,8 & 2,7 & Baik \\
\hline 2 & $\begin{array}{l}\text { menyampaikan informasi, } \\
\text { penjalasan dan argumen yang } \\
\text { dibahas. } \\
\text { Kedalaman dalam } \\
\text { menyampaikan informasi, }\end{array}$ & 2,6 & 2,6 & 2,7 & 2,6 & Baik \\
\hline 3 & $\begin{array}{l}\text { penjalasan dan argumen yang } \\
\text { dibahas. }\end{array}$ & 2,5 & 2,5 & 2,7 & 2,6 & Sedang \\
\hline 4 & $\begin{array}{l}\text { Kejelasan dalam } \\
\text { menyampaikan informasi, } \\
\text { argumentasi dan penjelasan } \\
\text { Kesesuaian antara argumentasi }\end{array}$ & 2,6 & 2,7 & 2,6 & 2,6 & Sedang \\
\hline 5 & $\begin{array}{l}\text { / jawaban dengan pertanyaan } \\
\text { Mampu mengkomunikasikan } \\
\text { hasil dalam bentuk diagram/ }\end{array}$ & 2,5 & 2,8 & 2,7 & 2,7 & Baik \\
\hline 6 & $\begin{array}{l}\text { tulisan } \\
\text { Kebakuan pemakaian } \\
\text { bahasa pada saat } \\
\text { menyampaikan informasi, }\end{array}$ & 2,8 & 2,7 & 2,8 & 2,8 & Baik \\
\hline 7 & $\begin{array}{l}\text { menyampaikan penjelasan dan } \\
\text { argumentasi. } \\
\text { Penguasaan materi yang dilihat } \\
\text { dari kelancaran berbicara saat } \\
\text { menyampaikan informasi, } \\
\text { menyampaikan penjelasan dan } \\
\text { berargumentasi. }\end{array}$ & 2,7 & 2,6 & 2,7 & 2,7 & Baik \\
\hline 8 & $\begin{array}{l}\text { Kesesuaian antara informasi, } \\
\text { argumentasi dan penjelasan } \\
\text { dengan konsep yang dipelajari. }\end{array}$ & 2,4 & 2,6 & 2,7 & 2,6 & Baik \\
\hline 9 & & 2,8 & 2,7 & 2,8 & 2,8 & Sedang \\
\hline & Rata-rata & 2,61 & 2,67 & 2,72 & 2,67 & \\
\hline & Nilai Kategori & sedang & Sedang & sedang & sedang & \\
\hline akan & $\begin{array}{l}\text { dangkan kualitas hasil be } \\
\text { tergambar dari ketunt } \\
\text { tor, ketuntasan individual, }\end{array}$ & & $\begin{array}{l}\text { ketunt } \\
\text { terhad } \\
\text { dikem }\end{array}$ & indi & $\begin{array}{l}\text { ikal } \\
\text { or y } \\
\text { eliti. }\end{array}$ & $\begin{array}{l}\text { nahasiswa } \\
\text { hg telah }\end{array}$ \\
\hline
\end{tabular}

akan tergambar dari prosentase aktivitas mahasiswa yang menunjukan aktivitas komunikasi ilmiah dan tingkat keterampilan komunikasi ilmiah mahasiswa selama pembelajaran. Ketuntasan Tes Hasil Belajar. 


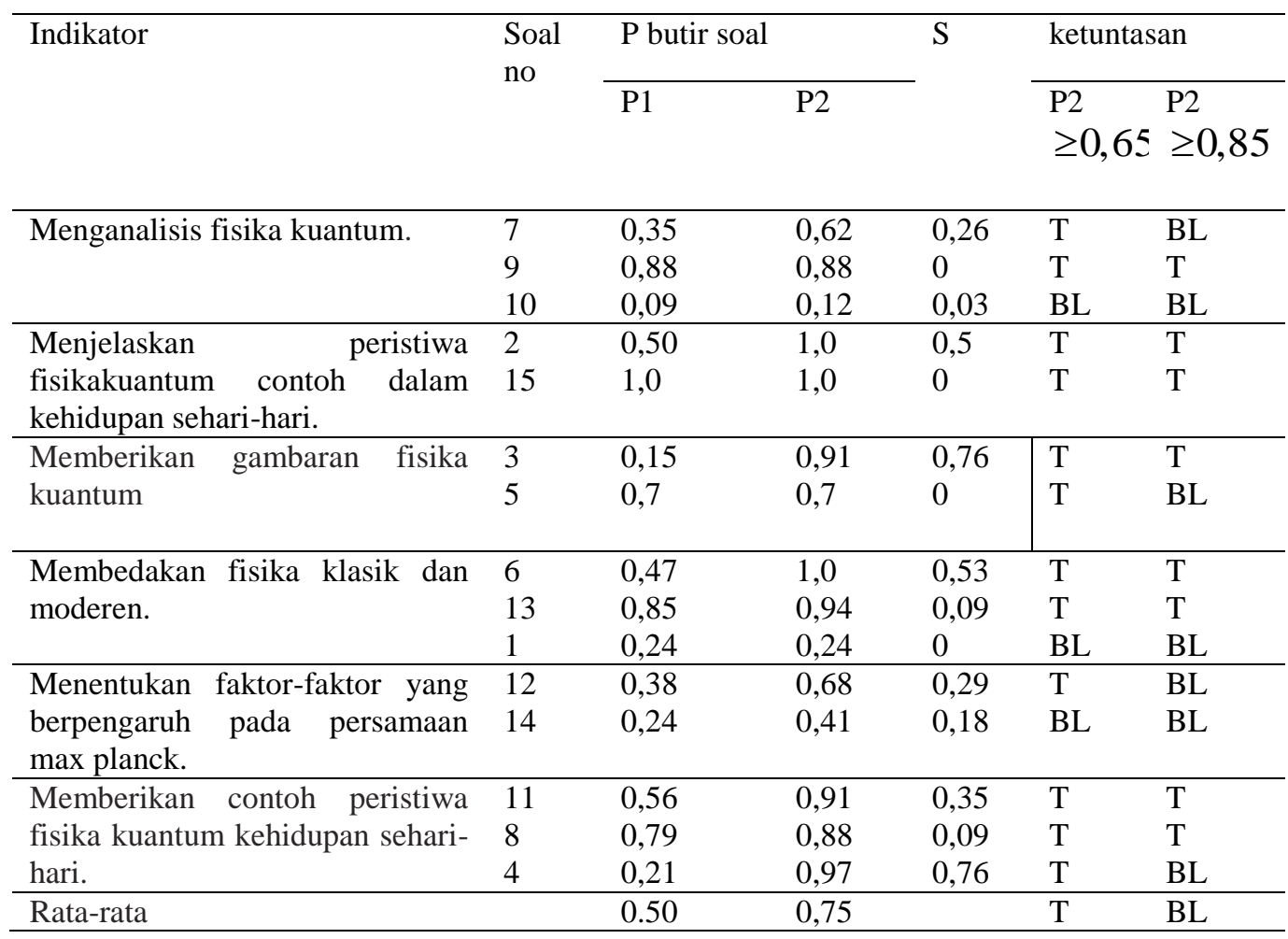

Keterangan:

P1 = Proporsi jawaban benar uji awal

$\mathrm{P} 2$ = Proporsi jawaban benar uji akhir

$\mathrm{S}=$ Sensitivitas butir soal

Kegiatan pembelajaran kooperatif jigsaw merupakan tahap diseminasi dari rangkaian penelitian ini, pembelajaran dibagi dalam enam fase diantaranya menyajikan rencana dan tujuan pembelajaran dan memotivasi mahasiswa, menyajikan informasi, mengorganisasikan mahasiswa ke dalam kelompokkelompok belajar, membimbing kelompok bekerja dan belajar, evaluasi dan memberikan penghargaan. Dalam pembelajaran jigsaw mahasiswa dibagi dalam kelompok asal dan kelompok ahli, dimana setiap anggota kelompok asal bertanggung jawab untuk mempresentasikan materi hasil diskusi kelompok asal dan bekerja secara kooperatif.

Aspek-aspek yang menggambarkan kualitas proses dan kualitas hasil belajar telah dicatat dan dianalisis. Hasil temuan selama kegiatan ujicoba yang telah dipaparkan pada hasil penelitian akan dibahas secara terpisah pada bagian ini. Hasil pembahasan ini, merupakan gambaran secara utuh dan menyeluruh dari penelitian yang berjudul "Pengembangan Model Pembelajaran Kooperatif Jigsaw yang Berorientasi pada Keterampilan komunikasi Ilmiah Siswa Dalam Matakuliah Fisika Kuantum”. Adapun pembahasan dari masingmasing data hasil penelitian adalah sebagai berikut:

\section{Pelaksanaan Disseminasi Perangkat Pembelajaran}

Pelaksanaan disseminasi dilakukan dengan mengimplementasikan perangkat pembelajaran pada pembelajaran kooperatif tipe jigsaw selama tiga kali pertemuan (3 SAP) dengan sub meteri masing-masing yang diajarkan. Dalam pembelajaran ini 
siswa melakukan serangkaian kegiatan seperti yang terdapat pada lembar kegiatan mahasiswa, setiap aktivitas yang dilakukan siswa selalu diamati oleh pengamat. Aktivitas mahasiswa difokuskan pada kemampuan mahasiswa mengkomunikasikan hasil kerja masing-masing baik secara lisan maupun tertulis. Model pembelajaran koooperatif jigsaw menyebabakan mahasiswa mampu melakukan komunikasi ilmiah terutama pada saat mahasiswa melakukan diskusi kelompok asal dan kelompok ahli, hal ini terlihat dari aktivitas mahasiswa dalam mengajukan pertanyaan dan menanggapi permasalahan baik dari mahasiswa kepada dosen atau dari mahasiswa kepada mahasiswa sehingga keterampilan komunikasi ilmiah masing-masing siwa dapat teramati.

Untuk menentukan tingkat pemahaman siswa maka pada setiap akhir pembelajaran diberikan quis. Pretest-postest diberikan kepada mahasiswa untuk menentukan tingkat penguasaan mahasiswa terhadap materi pelajaran secara menyeluruh. Selain itu diberikan juga penghargaan untuk tiga kelompok terbaik pada setiap awal pembelajaran untuk memberikan motivasi mahasiswa. Permasalahan yang terjadi pada disseminasi adalah peneliti kurang mampu dalam mengalokasikan waktu, hal ini terlihat dari penilaian pengelolaan pembelajaran bahwa dalam alokasi waktu evaluasi dan penutup masih kurang sehingga pembelajaran berakhir lebih 5 menit dari waktu yang ditetapkan, pada waktu kegiatan diskusi masih terlihat banyak sekali mahasiswa yang belum memanfaatkan waktunya secara maksimal, mahasiswa lebih terfokus pada pengerjaan tugas masingmasing ahli, mahasiswa juga merasa kesulitan dalam mengerjakan pertanyaan-pertanyaan kelompok ahli.

Berdasarkan pengamatan peneliti, masih terdapat perilaku menyimpang yang dilakukan oleh mahasiswa pada saat pembelajaran.

\section{Pengelolaan Pembelajaran}

Dalam penelitian ini juga terdapat penilaian pengelolaan pembelajaran, tujuan dari pengamatan pembelajaran ini untuk memantau pengelolaan pembelajaran yang dilakukan oleh peneliti dan sebagai bukti bahwa peneliti telah melakukan disseminasi di kelas menggunakan model pembelajaran kooperatif jigsaw.

Berdasarkan hasil pengelolaan pembelajaran peneliti belum bisa mengalokasikan waktu sesuai dengan SAP, kurang tegas dalam mengatur siswa serta kurang dalam memberikan kesempatan kepada mahasiswa untuk membaca referensi dan materi.

\section{Aktivitas Mahasiswa dalam Pembelajaran Kooperatif Jigsaw}

Berdasarkan hasil analisis deskriptif data pengamatan aktivitas mahasiswa sejumlah 20 siswa secara tetap menggunakan Instrumen 01 maka pada disseminasi I, II dan III diperoleh hasil koefisien reliabilitas instrumen secara berturut-turut adalah 76,3 \%, 75,7 \%, 76,9\%. Analisis deskriptif data aktivitas mahasiswa menunjukan bahwa perangkat pembelajaran yang dikembangkan mampu meningkatkan kecenderungan mahasiswa untuk melakukan komunikasi berkaitan dengan materi, hal ini terlihat selama pembelajaran berlangsung sebagian besar waktu mahasiswa digunakan untuk melakukan komunikasi mengenai materi baik antara mahasiswa dengan dosen maupun antar mahasiswa dengan mahasiswa 
(mempresentasikan hasil $=6,2 \%$, mendengarkan mahasiswa lain dan tidak memotong presentasi $=12,8 \%$, bertanya aktif kepada dosen dan mahasiswa $=8,7 \%$, memberikan tanggapan permasalahan $/$ pendapat $=$ $9,6 \%$, membaca $=13,2 \%$, menulis $=$ $10,5 \%$ dan mengerjakan LKM/bekerja dengan alat $=14,1 \%$ ). Apabila dilihat aktivitas mahasiswa dalam pembelajaran kooperatif jigsaw tersebut, maka aktivitas mahasiswa pada disseminasi I, II dan III yang menonjol adalah kegiatan mengkomunikasikan materi.

\section{Nilai \\ Komunikasi \\ Keterampilan Mahasiswa}

Berdasarkan hasil analisis deskriptif data pengamatan aktivitas mahasiswa sejumlah 20 siswa (5 kelompok sampel) oleh 10 pengamat secara tetap menggunakan instrumen 02 maka pada disseminasi I, II dan III diperoleh hasil koefisien reliabilitas instrumen secara berturutturut adalah 75,6\%, 75,0\%, 76,1\%. Analisis deskriptif data nilai keterampilan komunikasi ilmiah mahasiswa pada disseminasi I, II dan III menunjukan bahwa keterampilan komunikasi ilmiah mahasiwa menggunakan pembelajaran kooperatif jigsaw adalah berhasil, hal ini terlihat dari tingkat keterampilan komunikasi ilmiah mahasiswa pada kategori sedang sampai baik, dengan skor rata-rata adalah 2,67 = sedang. Nilai keterampilan komunikasi ilmiah mahasiswa belum optimal secara menyeluruh karena masih terdapat beberapa mahasiswa yang belum menguasai materi.

\section{Deskripsi Hasil Belajar Mahasiswa}

Deskripsi hasil belajar siswa menunjukan bahwa dalam pembelajaran yang dilakukan oleh peneliti diperoleh rata-rata proporsi jawaban benar uji awal adalah 0,5 dan rata-rata proporsi uji akhir adalah 0,75. Apabila diterapkan angka ketuntasan menurut kurikulum yaitu proporsi jawaban benar uji akhir (p2 $\geq 0,65$ ) maka hasil belajar tersebut sudah tuntas, sedangkan menurut Designing Effective Instruction (Kemp, Morrisson, 1994: 286) dalam Insih Wilujeng (1999: 130) yaitu proporsi jawaban benar uji akhir (p2 $\geq 0,85)$ maka hasi belajar siswa tersebut belum tuntas. Berdasarkan acuan tersebut maka ketuntasan pembelajaran yang dicapai masih terdapat beberapa butir soal yang belum tercapai ketuntasannya.

Sensitivitas butir soal dapat tercapai jika Sensitivitsas $(S) \geq 0.40$ maka butir soal tersebut peka terhadap efek-efek pembelajaran (Arikunto S, 1991 dalam www.damandiri.or.id: 13 November 2006). Berdasarkan hasil penelitian tersebut maka butir soal yang mencapai sensitivitas tinggi adalah butir soal nomor 2, 3, 6, dan 4 sedangkan untuk butir soal yang sensitivitasnya masih rendah adalah butir soal no $9,15,5,1$.

\section{KESIMPULAN}

Berdasarkan hasil penelitian tindakan kelas, dapat disimpulkan bahwa: Langkah-langkah pengembangan perangkat pembelajaran model kooperati jigsaw yang berorientasi keterampilan komunikasi ilmiah mahasiswa pada matakuliah fisika kuantum, mengikuti pola 4-D Model : Define, Design, Develop, Disseminate. Tahap Define ditandai dengan dihasilkannya kebutuhan-kebutuhan di dalam proses pembelajaran, Design ditandai dengan hasil akhir berupa Draft awal perangkat pembelajaran yang akan dikembangkan, sedangkan tahap 
Develop berupa pengembangan perangkat pembelajaran lebih lanjut, dan sebagai akhir tahapan yaitu Disseminate dengan pengujian perangkat pembelajaran. Analisis deskriptif data aktivitas mahasiswa menunjukan bahwa perangkat pembelajaran yang dikembangkan mampu meningkatkan kecenderungan mahasiswa untuk melakukan komunikasi berkaitan dengan materi adalah 75,1\%, Analisis keterampilan komunikasi ilmiah mahasiswa menunjukan bahwa keterampilan komunikasi ilmiah mahasiswa sedang pada pembelajaran kooperatif jigsaw adalah 2,67 dan hasil belajar mahasiswa tuntas.

\section{DAFTAR RUJUKAN}

Anita Lie. 2004 Cooperative Learning mempraktikan Cooperative Learning di Ruang-Ruang Kelas. Jakarta:Grasindo

Fitri Rahmawati. 2006. Strategi Pencapaian Kualitas Pembelajaran;

http://www.uny.ac.id/home/ar tikel (11 november 2006 )

Insih Wilujeng. 2006. Peningkatan Penguasaan Teknologi Pembelajaran dan Kemandirian Aktif Siswa Melalui Pemilihan Model Pembelajaran (Makalah Lokakarya Pengembangan Model-model Pembelajaran, program PHK A2 tanggal 26 dan 27 Juli 2006 ) Jurusan Pendidikan Fisika, FMIPA : Universitas Negeri Yogyakarta.

Perdy Karuru, Penerapan Pendekatan Keterampilan Proses dalam Seting
Pembelajaran Kooperatif

Tipe STAD untuk

Meningkatkan Kualitas

Belajar IPA Siswa SLTP: www.depdiknas.go.id

Rukman Nugraha. 2004. Pendidikan Sains Kita. www.sampoernafoundation.o rg (11 November 2006 )

Suharyanto, 2005. Model - model Pembelajaran ( makalah workshop ). Jurusan Pendidikan Fisika, FMIPA : Universitas Negeri Yogyakarta.

Umaedi, 1999. Manajemen Peningkatan Mutu Berbasis Sekolah: ssep.net/director.html. ( 13 November 2006) 